\title{
Job Satisfaction and Job Commitment: A Study of Quantity Surveyors in Nigerian Public Service
}

\author{
Luqman Oyekunle Oyewobi, Bolaji Suleiman \& Abubakar Muhammad-Jamil \\ Department of Quantity Surveying, Federal University of Technology \\ Minna, Niger State, Nigeria \\ E-mail: Oyekunlehassankay@yahoo.com
}

Received: November 14, 2011

Accepted: January 29, 2012

Published: March 1, 2012

doi:10.5539/ijbm.v7n5p179

URL: http://dx.doi.org/10.5539/ijbm.v7n5p179

\begin{abstract}
While job satisfaction is a major concern in today's organizations, there is little empirical research concerning Quantity Surveyors in public sector in Nigeria. Primary data were sourced through survey of Quantity Surveyors in various ministries and parastatals by adopting Job Satisfaction Questionnaire used by previous researchers to elicit information under the two headings for general satisfaction scale to indicate their satisfaction or dissatisfaction with research variables along a five-point scale. The data were subjected to descriptive statistics, this paper examined the the major variables affecting job satisfaction amongst Quantity surveyors working in Nigerian public sectors at federal level. The research revealed that Quantity Surveyors in public service are more satisfied with their when adequate recognition is given and opportunities for advancement are encouraged. The result of the correlation also showed that strong positive relationship existed between adequate recognition opportunities and feeling of accomplishment derived from the job with the r-value of $85 \%$. The research recommended that advancement opportunity in career progression and professional development such as in-house training should be encouraged to improve quality service delivery and also practice of job development and job enrichment in the workplace which is vital tool to satisfy employees and make them happy should be given adequate attention.
\end{abstract}

Keywords: Job satisfaction, Job commitment, Public service, Quantity Surveyors, Nigeria

\section{Introduction}

Since 1959 when Herzberg, Mauser and Snyderman carried out a study on the "motivation to work"; they came up with the development of the "Two-Factor Theory of job satisfaction". The developed theory was based on interview of over two hundred professionals specifically, accountants and engineers in Pittsburgh and Pennsylvania to determine the factors responsible for job satisfaction and dissatisfaction (Herzberg et al., 1959). This was later researched further to explore factors responsible for job dissatisfaction Herzberg (1987) and Herzberg (2003). Since after the study was conducted, organizational behaviorists and human resources researchers in both private and public sectors viewed the subject of job satisfaction to be one of the most studied work related attitudes (Bedeian, Ferris, \& Kacmar, 1992; Clark 1997; Durst \& DeSantis, 1997; Ellickson \& Logsdon, 2001; Jung \& Moon, 2007; Lewis, 1991; Ting, 1997; Wright \& Kim, 2004). Kinicki, McKee-Ryan, Schriesheim, Carson, (2002) and Kreitner \& Kinicki, (2007) argued that it is little wonder that over 12,000-job satisfaction studies were published by the early 1990s, the concept has been increasingly sophisticated and challenged. The concept of job satisfaction is very abstract and complex, even opined to be indescribable and mythical (Malik, 2011).

The principles underlying job satisfaction and motivation are closely related to each other, and to foster an effective and productive workplace the two concepts should not be divorced (Mowday et al., 1982; Mathieu and Zajac, 1990; Bono et al., 2001; Koys, 2001; Chen and Francesco, 2003, Greguras et al., 2004; Tziner et al., 2008). The importance of these two concepts was stressed in Loosemore, Dainty and Lingard (2003) as germane to the wellbeing of the construction industry in which the study population operates. Koys (2001), Chen and Francesco (2003) and Tziner et al. (2008) asserted that the relative success of organizations has been tied to the two motivational constructs of work satisfaction and organizational commitment. Garcia-Bernal et al. (2005) in their study of job satisfaction with respect to gender differences argued that with job satisfaction perceived to be 
a pre-condition for competitive levels of quality to be recorded and for organization to be successful then employee satisfaction should be cardinal to organizational objective.

The main aim of this paper is to identify the major variables affecting job satisfaction amongst Quantity surveyors working in Nigerian public sectors at federal level and the specific objectives include; to investigate the impact of job satisfaction on Quantity Surveyors performance; the motivating factors that enhances organisational commitment, the relationship that exists between job satisfaction and organisational commitment on the satisfaction derived from work. Many research have evolved or been carried out on job satisfaction or performance of professionals operating within the construction industry and various industries (Chileshe and Haupt, 2007; Bowen et al., 2008; 2009) very few of them are within the African context as the majority of the researches focuses on the developed countries. This research becomes necessary because many Quantity surveyors in Nigerian Federal ministries and Parastatals are getting disenchanted with lack of recognition or professional encroachments being experienced within their organisation. A typical instance to buttress this submission was statements credited to a sitting minister of works and transport Ogunlewe (2005) in a public hearing on due process and procurement bill submitted that "We are talking of Due Process, shouting Due Process. What is Due Process? In the Federal Ministry of Works where I preside as the Minister, I don't believe there is anything that is Due Process. How can there be Due Process when the Engineer designs the roads, estimates the costs of the roads, selects the contractor, constructs the roads, supervises the construction, recommends payment for works done, approves the payment, certifies the quality and quality of work! All these by one person! Haba! This cannot be Due Process. Not until roles are assigned to relevant professionals like the Quantity Surveyors to be in charge of cost and cost management of roads and highways, can there be any Due Process in Federal Ministry of Works."

Also Adebola (2006) posited that "I also know from experience, especially in the public service, that most Quantity Surveyors are becoming despair about the manner in which Quantity Surveying is being excluded from the highway sector". Infrastructure Concession Regulatory Commission (Establishment etc) Act 2005 and the Public Procurement Act 2007 have Quantity Surveying profession totally excluded as a player within the acts, all of these make quantity surveyors get disillusioned and when workers are not happy it may be difficult to offer their best. Patterson et al. (2004) reported that research in European countries and the U.S. suggests that individual job satisfaction can be a strong predictor of job performance and productivity.

Thus, it becomes highly imperative to have an understanding of what variables lead to key increases in work satisfaction and organizational commitment (Westover et al., 2010) and to empowers employers to make workplace adjustments that will raise the motivation levels and ultimately the performance of their workers (westover et al., 2010).

\section{Concept of Job Satisfaction}

Job satisfaction is viewed as an attitude that relates to overall attitudes towards life, or life satisfaction (e.g., Tait et al., 1989; Ilies et al., 2009) as well as to service quality (Schneider and Bowen, 1985; Hartline and Ferrell, 1996). Duffy and Richard (2006) while carrying out their research across six major specialties among physicians opined that exploring the prediction of job satisfaction is extensive and stressed further that recently, theorists have proposed that job satisfaction may be equally affected by issues related to work and by personality characteristics.

Tovey and Adams (1999) reported that relevant dimensions of job satisfaction appear to be situational and depending on the particular characteristics of the work environment and on the period in which the studies took place. Job satisfaction has been included in more than 50 studies of job insecurity (Sverke et al., 2006). Jobs provide many sources of satisfaction. They ensure economic stability, provide social interaction, and offer reinforcement contingencies that enhance self efficacy (De Witte, 1999).

\section{Previous Research on Job Satisfaction}

Chileshe and Haupt (2007) and Bowen et al., (2008; 2009) classified previous researches conducted on job saisafction and on workers in general fall into the following categories:

> Prediction of psychological wellbeing in terms of workers health and job satisfaction (Clark, 1997; Loosemore et al., 2003; Love and Edwards; 2005; Wright et al., 2007).)

Impact of corporate wellness on stress, satisfaction and absenteeism (Ho, 1997)

$>$ Linkages between organizational networking and cultural organizing (Fletcher, 2002) 
> Impact of age on job satisfaction (Rhodes, 1983; Luthans and Thomas, 1989; Holden and Black, 1996; Hickson and Oshagbemi, 1999; Oshagbemi, 2000; Eskildsen et al., 2003 Okpara, 2004; Moyes et al., 2006)

$>$ Linkages between customer satisfaction and service workers perceived control (Yagil, 2002)

$>$ Barriers to empowerment (Greasley et al. 2005; Holt et al., 2005)

$>$ Assessment of universal forms of work commitment (Freund and Carmeli, 2003)

$>$ Testing the applicability of Herzberg's two-factor theory (Bassett-Jones and Lloyd, 2005; Ruthankoon and Ogunlana; 2003).

$>$ Relevance of job satisfaction and how it impacts the physical and mental well being of employees (Oshagbemi 2000a)

> The linkages between the length of service in employment and satisfaction have also been examined in the academia related organizations (Oshagbemi, 2000b)

$>$ Leadership style (Rad and Yarmohammadian, 2006);

Dork characteristics and characteristics of the work environment (Irvine and Evans, 1995);

$>$ Job security or insecurity (Yousef, 1998; Reisel et al., 2007)

> Disability and workplace characteristics (Uppal, 2005);

$>$ Adverse working conditions (Bockerman and Ilmakunnas, 2006);

$>$ Size of business (Davis, 2004); and

$>$ Socio- and racio-ethnic differences in perceptions (Sloane and Williams, 2000; Friday and Friday, 2003; Friday et al., 2004).

$>$ Public service motivation (Leonard,2008)

$>$ Job satisafaction among construction professionals ( Bowen et al.,2007; Bowen, 2008; 2009; Chileshe and Haupt, 2007)

Not all findings are conclusive, with contradictory findings being reported (Koustelios, 2001) and therefore, more research are required to unfold events in every areas of human endeavors.

Moynihan and Pandey (2007) submitted that in the area of work motivation it is expected that organizations will have greatest influence over job satisfaction, less influence over employee commitment, and the least influence over employee involvement.

\section{Factors Influencing Job Satisfaction}

According to Rue and Byars (2005) it was viewed that job satisfaction leads to an increased commitment to one's organization and Jernigan and Beggs (2010) concluded that more substantial attention has to be given to the relationship that exists between organizational commitment and job satisfaction, which may generate findings that may be useful in developing the understanding of the links between satisfaction and management substitutes. Gautam; Mandal and Dalal (2006) argued that job satisfaction of an employee either in public or private organization is a topic that has received considerable attention by researchers and managers alike and Roznowski \& Hulin (1992) reported that the most essential information to have regarding an employee in an organization is a validated measure of his/her level of job satisfaction

Therefore, work conditions was found to be the most influential on the job satisfaction and that public employees turnover intentions were more of intrinsic nonmonetary characteristics of their work, such as good social relationships with coworkers and supervisors, promotion opportunities, professional development opportunities, and participatory management strategies (Emmert \& Taher, 1992; DeLeon \& Taher, 1996; Kim, 2002, Ellickson, 2002; Wright \& Davis, 2003; Kim, 2004;Borzaga \& Tortia, 2006). Also,there is a string in some literature that corroborated the assertion of the earlier authors that job satisfaction scores can explain employees' intentions to quit or actual quits (Ward and Sloane, 2000; Clark, 2001; Shields and Price, 2002; García-Serrano, 2004; Kristensen andWestergård- Nielsen, 2004; Sousa-Poza and Henneberger, 2004; Delfgaauw, 2007; Lévy-Garboua et al., 2007

Although some scholars reported that public employees do have acceptable levels of job satisfaction, burnout among other things was found to be a major threat in public organizations. This is rooted in the submission of (Naff \& Crum, 1999; Kamdron, 2005) that there is evidence that Permanent status with respect to nature of appointment of employees is negatively related to the job satisfaction of public employees. 
Ting (1997) assertion that interpersonal relations are imperative to job satisfaction reiterated the report of Khojasteh (1993), Kim (2002) in his research carried out to examining the relationship between participative management and job satisfaction reported that more inclusive and participatory styles of management also foster increased job satisfaction. These earlier arguments was also buttressed by Ellickson (2002) who also found that the sense of esprit de corps as used my military people was the most influential predictor of job satisfaction in his sample of municipal employees, whereas Steijn (2004) opined in his research on Human resource management and job satisfaction in the Dutch public sector that organizational climate was important in predicting job satisfaction. In another research carried by Cummings (2007) among IT workers indicated that working conditions/ work environment, the corporate culture, job peers, and the challenge derived from the job itself are the top rated factors capable of influencing job satisfaction.

\section{Effects of Job Satisfaction or Dissatisfaction}

With respect to previous research findings reported in (George, 1992; George \& Jones, 2008; Ghazzawi, 2008-b; Ghazzawi \& Smith, 2009; Judge \& Locke, 1993; Robbins and Judge, 2009; Rue \& Byars, 2005) the consequences of job satisfaction includes: organizational commitment; organizational citizenship behavior (OCB), and employee well-being. However; the consequences of job dissatisfaction was also highlighted which are: absenteeism; turnover intentions, and turnover (George, 1992; George \& Jones, 2008; Ghazzawi, 2008-b; Ghazzawi \& Smith, 2009; Judge \& Locke, 1993; Robbins and Judge, 2009). Mathieu and Zajac (1990) suggested that the higher performance, the greater satisfaction derived and the lower the turnover intention of workers, therefore, low levels of organizational commitment may be dysfunctional not only to the organization but also to the individual, while high levels of organizational commitment may have positive effects on both the organization and the employee.

\section{Organizational Commitment}

Allen and Meyer (1990) classified organizational commitment into three basic elements. The three component of organizational commitment includes affective, continuance and normative as the three dimensions of organizational commitment. He viewed affective commitment as the employee's emotional attachment to, identification with, and involvement in the organization. The continuance component refers to commitment based on the costs that the employee associates with leaving the organization. The normative component refers to the employee's feeling of obligation to remain with the organization.

Schwepker (2001) reported previous researches in his study of ethical climate's relationship to job satisfaction, organizational commitment, and turnover intention in the salesforce and it was viewed that organizational commitment acts as a "psychological bond" to the organization that inspires individuals to act in ways that are harmonious with the concerns of the organization. Zeinabadi (2010) reported that "Organizational commitment is the strength of an individual's identification and involvement in a particular organization as characterized by a strong belief in and acceptance of the organization's goals and values (value commitment) along with a readiness to exert considerable effort on behalf of the organization and to remain a member (commitment to stay ) ( $\mathrm{p}$. 999)"

\section{Role Clarity, Job Characteristics and Self Efficacy}

Ting (1997) found that clarity of tasks leads to greater job satisfaction among workers. Role clarity provides a sense of purpose and increases the individual's belief that the goal is achievable individually and collectively. Greater role clarity will create employees who are more satisfied with, committed to, and involved in their work. Job characteristics are aspects of the individual employee's job and tasks that shape how the individual perceives his or her particular role in the organization. Goal theory suggests that goals that are both specific and difficult to achieve lead to higher performance than goals that tend to be easy or ambiguous (Locke \& Latham, 1990).

Bandura (1986) viewed self-efficacy as the judgments of individuals regarding their ability to organize and perform daily works required to obtain successful performance. O'Neill and Mone (1998), Krishnan et al. (2002), Zellars (2001) and Karatepe et al (2006) submitted that that there is a positive correlation and direct relationship between self-efficacy and effort. Bradley and Roberts (2004) reported that self-efficacy is capable of increasing the job satisfaction of self-employed individuals. McFarland and Buehler, (1995) also opined that self-efficacy is an individual construct and that it can also be affected by group-level effects such as group-efficacy. Therefore, project team members who believe that they can contribute project success by sharing knowledge will develop greater positive willingness to contribute to share knowledge (Lin, 2007) and this is line with the assertion of Wasko and Faraji (2005) that self-efficacy can help motivate individuals to share knowledge with colleagues. Knowledge self-efficacy reveals in people confidence that their knowledge can help to solve problem of organization and increase work efficacy (Luthans, 2003). 


\section{Research Methods}

The research adopted survey method its approach using questionnaire as the main tools for exploring the opinions of the sample of Quantity Surveyors in Nigerian Federal Civil Service with respect to job satisfaction and job commitment. Well structured questionnaire previously used by Bright (2008) and Moynihan and Pandey (2007) which identified job satisfaction and job/organisational commitment was used for the data collection and the survey involved a random selection of potential participants from the available Quantity Surveyors in the study area. The target population for this research is the registered Quantity surveyors (QS) working in the Nigerian Public service. This is on the premise that registered QSs have the opportunity of crystallizing their ambition elsewhere or go into private practice.The questionnaires were self administered during the annual meeting of Quantity surveyors working in Government ministries and parastatals. Due to a large number of the population size of all Registered Quantity Surveyors in the Nigerian Public Service, the sampling frame was delimited to all Federal Ministries, Parastatals and Agencies within the Federal Capital Territory, Abuja

The study employed Non- probabilistic sample of Seventy five (75) Registered Quantity Surveyors in the employment of Nigeria's public service were administered with the questionnaires, Sixty (61) numbers of the questionnaires were returned by the respondents. This was adopted because of non availability of comprehensive list of registered Quantity surveyors in the public service within the Federal Capital Territory, Abuja.

The respondents were given statements and were asked to assess the importance of these factors on a 5 - point Likert scale The respondents were asked to score on a scale of 1 to 5 , the level of agreement with the statements as it relates to working in the Nigerian Public Service using 1 for strongly disagree, 2 disagree, 3 neutral, 4 for agree and 5 for strongly agree. The data sourced were analyze using basic descriptive statistics (Pearson Correlations, standard Deviations, means) to explore the relationship between Job satisfaction and organizational commitment.

\section{Reliability Test}

Reliability has to do with the accuracy and precision of measurement procedure (Cooper and Emory, 1995). Sekaran (2003) opined that Cronbach's alpha is a reliability coefficient that reflects how well the items in a set are positively correlated to one another. Sekeran (2003) argue further that a study is only reliable only if another researcher, using the same procedure and studing the same phenomenon, arrives at similar or compatible findings. Therefore, Cooper and Emory (1995) submitted that the scientific requirements of a research call for measurement process to be reliable and valid. Sekaran (2005) argued that if the cronbach's alpha reliability test result is less than 0.6, it thus mean that the instrument used has low reliability and therefore gives room for some errors but if the alpha value is within 0.7 , the instrument is reliable.

Hence, the internal consistency reliability coefficients for the scaled employed by this is 0.85 for job satisfaction and 0.9 for job commitment, which is above the level of 0.7 posited by sekaran (2005) as acceptable for the purpose of analysis.

\section{Results and Analysis}

The tables showed the mean value, standard deviation as well as skewness and kurtosis results. Curran, West, and Finch (1995) as cited in Bright (2008) suggested that data could be said to be in excellent condition if skewness ranges is fewer than 2 and kurtosis ranges fewer than 7 .

Table1 showed the descriptive analysis result of Job Satisfaction and the results of the analysis affirmed the assertion of the authors, thus the result is good enough for the research. Recognition of opportunities was ranked first with mean value (Mean=3.803, $\mathrm{SD}=0.128$ ), advancement opportunities was ranked second with mean value (Mean=3.314, SD=0.787), level of responsibility on the job was ranked third with mean value (Mean=3.294, $\mathrm{SD}=1.026$ ) and Opportunities for achievement was ranked fourth with mean value (Mean=3.255, $\mathrm{SD}=0.796$ ). The views of respondents were based on the impact of these variables on Job satisfaction, the respondents were asked if they were satisfied with the work all in all, this showed mean value of (Mean=3.75, $\mathrm{SD}=0.896$ ). High mean values showed that quantity surveyors are satisfied with their work and high standard deviation denoted dissatisfaction; therefore, quantity surveyors would be more satisfied with their job if their work and efforts are more recognized.

Table 2 showed the descriptive analysis result of Organizational Commitment within the organization and the results from the table was in tune with the results shown in table1. From the table, Feeling of accomplishment from the Job exhibited the highest ranking with mean value (Mean=3.784, $\mathrm{SD}=0.966$ ), the organization deserving Loyalty was ranked second with a mean value (Mean=3.549, $\mathrm{SD}=1.045$, getting praised for doing a good job was ranked third with of (Mean $=3.412, \mathrm{SD}=0.92$ ) mean value and having sense of obligation to people 
within an organisation was ranked last with (mean $=3.294, \mathrm{SD}=0.901$ ). The respondents view was based on the impact of the variables on Organisation commitment.

From table 3 and the result of analysis carried out to test whether there was significant relationship among the variables tested; Pearson's (r) correlation was calculated. The correlation coefficient for the data revealed that variables tested were significantly related. The result of the correlation between job satisfaction and job commitment variables are significant at 1 and $5 \%$ respectively. The significance of the relationship was demonstrated by correlation between opportunities for achievement and owing a great deal to the organisation with the values of $\mathrm{r}=+0.499, \mathrm{p}<0.01$. Also, correlation between recognition opportunities and feeling of accomplishment derived from the job show the values of $r=+0.855, p<0.01$. Hikkles, Wiersma and Jurs (1998) as cited in Oyewobi et al (2011) recommended that correlation in the range of $70 \%(0.70)$ to $90 \%(0.90)$ is high and $50 \%(.50)$ to $70 \%(.70)$ is moderate. This rule is pertinent in this respect since r- value is used in determining the strength of the relationship, which indicates that an increase in one variable give rise to a corresponding increase in the other (Love, 2002). Thus, the correlation between opportunities for achievement and owing a great deal to the organization is moderate because $50 \%$ approximately means that there is a positive moderate correlation between the variables. Therefore, as the opportunities for achievement slopes from left to the right, owing a great deal to the organization variation also increases.

The correlation analysis also revealed that the level of responsibilities and the praise gotten for doing a good job are significantly related, $r=+0.590, p<0.01$. However, the $r(59.0)$ value is moderate considering the rule stated above, which means the more occurrence of the level of responsibilities, there is going to be increase in praise of doing a good job.

\section{Discussion of Results}

The result of the analysis revealed that Quantity Surveyors are more likely to be satisfied and motivated with their job if they are given adequate recognition and more opportunities to advance in their career. This is supported by Kreitner and Kinicki (2007) who argued that value is positively associated with Job Satisfaction. Thus Quantity surveyors in Public service motivator for job satisfaction are intrinsic since it involves the expectation that work should be satisfying irrespective of the pay or compensation (George and Jenes, 2008). Drafke and Kossen (2002) was of the opinion that many workers experience satisfaction when they believe that their future prospects are bright and good and this may according to Bull (2005) "translate into opportunities for advancement and growth in their current workplace, or enhance the chance of finding alternative employment". It was stressed further that if people feel they have limited opportunities or chance for career advancement in any organization, their job satisfaction may decrease which consequently may lead to job turnover.

The result of the correlation analysis showed that positive relationships exist amongst the variables of job satisfaction and job commitment tested. The researcher choose to correlate the two factors in line with the submission of Udo et al. (1997) that job satisfaction and organisational commitment are both reflecting a positive evaluation of the job. Strong relationship existed between recognition opportunities and feeling of accomplishment among the Quantity surveyors in the federal civil service. Other variables tested exhibited moderate positive relationship.

This indicated that Quantity surveyors are more committed to their jobs when adequate opportunities for advancement and achievement with due recognition. Guleryuz, Guney, Aydin and Asan (2008) in their research carried out among nurses which focused on investigate the relations among emotional intelligence, job satisfaction, organisational commitment and the mediating effect of job satisfaction between emotional intelligence and organisational commitment submitted significant relationship existed between job satisfaction and organisational commitment. Lum et al., (1998); Cohen and Hudacek,(1998) and Becker et al, (1996) asserted that lack of organisational commitment has detrimental effects such as increase in turnover rate and turnover intention; higher absenteeism and tardiness; poorer performance which are affecting organisational efficiency and effectiveness negatively.

\section{Conclusions}

After examining the effects on Job Satisfaction and job commitment among Quantity Surveyors in the Nigerian Public Service, the research work concludes thus; Quantity surveyors in Nigerian public service enjoy their job when adequate recognitions are given. Enhancement of job satisfaction with advancement opportunities and professional development has significant effect on Quantity Surveyors in Nigerian public service.

Quantity surveyors in Nigerian Public service are more satisfied with their job when there is clarity of job as planned goals, objectives and having the chance to work alone. Role clarity plays an important role to commit 
employees to their jobs. The findings revealed that strong positive correlation do exist between variables of job satisfaction and job commitment. This implies that Quantity surveyors in the Nigerian public service are more committed to their job when they derive more satisfaction in their job.

\section{Recommendations}

From the conclusions, the following recommendations were made; adequate recognition of the work Quantity surveyors in the public service should be fully appreciated and encroachment by other professionals should be highly discouraged. Advancement opportunity in career progression and professional development such as in-house training should be encouraged to improve quality service delivery and also practice of job development and job enrichment in the workplace which is vital tool to satisfy employees and make them happy should be given adequate attention. The work to be done by Quantity surveyors should have clear goals, objectives and interference by other professionals should be checked. It is important that Government involve quantity surveyors in their goals' formulation process as these goals directly affect their performance within the organization. In the same vein, an apt performance feedback on employees' progress is highly necessary to achieve the required performance expected from them and rewards. If quantity surveyors in the Nigerian public service are to be committed to their job, all aspects of job satisfaction should be taken care of that is the affective, continuance and normative.

It is important to note that this research only considered registered Quantity surveyors in the Federal Ministries and parastatals, so the result should be cautiously considered and probably replicated since it was only relationship between job satisfaction and organizational/job commitment that was focused and not the fundamental connections among the variables considered.

\section{References}

Adebola O. (2006). The Quantity Surveyor in highway development. Paper presented at the $22^{\text {nd }}$ Biennial conference/general meeting on Quantity surveying in the $21^{\text {st }}$ Century - Agenda for the Future. Nigerian Institute of Quantity Surveyors.

Allen, N.J., \& Meyer, J.P. (1990). The measurement and variables associated with affective,continuance and normative commitment to the organization. Journal of Occupational Psychology, 63, 1-18. http://dx.doi.org/10.1111/j.2044-8325.1990.tb00506.x

Bandura, A. (1986). Social Foundations of Thought and Action: A Social Cognitive Theory. Prentice Hall, Englewood Cliffs, NJ.

Bassett-Jones, N., and Lloyd, G.C. (2005). Does Herzberg's motivation theory have staying power?. Journal of Management Development, 24(10), 929-943. http://dx.doi.org/10.1108/02621710510627064

Becker, T.E., Robert, S.B., Daniel, M.E., \& Nicole, L.G. (1996). Foci and bases of employee commitment: implications for job performance. Academy of Management Journal, 39 (2), 464-482. http://dx.doi.org/10.2307/256788

Bedeian, A., Ferris, G., \& Kacmar, K. (1992). Age, tenure, and job satisfaction: A tale of two perspective. Journal of Vocational behavior, 40, 33-48. http://dx.doi.org/10.1016/0001-8791(92)90045-2

Bockerman, P., and Ilmakunnas, P. (2006). Do job disamenities raise wages or ruin jobsatisfaction?. International Journal of Manpower, 27(3), 290-302. http://dx.doi.org/10.1108/01437720610672185

Bono, J.E., Judge, T.A., Patton, G.K., and Thoresen, C.J. (2001). The job satisfaction-job performance relationship: a qualitative and quantitative review. Psychological Bulletin, 127(3), 376-407. http://dx.doi.org/10.1037/0033-2909.127.3.376

Borzaga, C., \& Tortia, E. (2006). Worker motivations, job satisfaction, and loyalty in public and nonprofit social services. Nonprofit and Voluntary Sector Quarterly, 35, 225-248. http://dx.doi.org/10.1177/0899764006287207

Bowen, P. (2008). Job satisfaction of quantity surveyors: differences on the basis of demographic descriptors explored. The construction and building research conference of the Royal Institution of Chartered Surveyors (COBRA 2008), Dublin Institute of Technology, 1-29. http://dx.doi.org/10.1108/09699980810867415

Bowen, P., and Cattell, K. (2008). Job satisfaction of South African quantity surveyors. Engineering, Construction and Architectural Management, 15(3), 260-9.

Bowen, P.A., Cattell, K.S., Distiller, G., and Michell, K.A. (2007). Job satisfaction of SA quantity surveyors: a racial analysis. Journal of Contemporary Management, 4, 86-115. 
Bradley, D. E., \& Roberts, J. A. (2004). Self-employment and job satisfaction: Investigating the role of self-efficacy, depression, and seniority. Journal of Small Business Management, 42(1), 37-58. http://dx.doi.org/10.1111/j.1540-627X.2004.00096.x

Bright, L. (2008). Does Public Service Motivation Really Make a Difference on the Job Satisfaction and Turnover Intentions of Public Employees? The American Review of Public Administration, 38(2) 149-166. http://dx.doi.org/10.1177/0275074008317248

Bull, I. H. F. (2005). The relationship between job satisfaction and organisational commitment amongst high school teachers in disadvantaged areas in the Western Cape. Mini-thesis submitted in partial fulfilment of part of the requirements, for the degree of Magister Artium, in the Department of Industrial Psychology, Faculty of Economic and Management Science, University of the Western Cape.

Chen, Z.X., and Francesco, C. (2003). The relationship between the three components of commitment and employee performance in China. Journal of Vocational Behavior, 62(3), 490-510. http://dx.doi.org/10.1016/S0001-8791(02)00064-7

Chileshe, N and Haupt, T C. (2007). Age influences on the job satisfaction of construction workers: evidence from South Africa. In: Boyd, D (Ed) Procs 23rd Annual ARCOM Conference, 3-5 September 2007, Belfast, UK, Association of Researchers in Construction Management, 389-390.

Clark, A. (1997). Job satisfaction and gender: why are women so happy at work? Labour Economics, 4(4), 341-372. http://dx.doi.org/10.1016/S0927-5371(97)00010-9

Clark, A.E. (2001). What really matters in a job? Hedonic measurement using quit data. Labour Economics, 8 , 223-242. http://dx.doi.org/10.1016/S0927-5371(01)00031-8

Cohen, A., \& Hudacek, N. (1998). Organisational commitment turnover relationship across occupational groups. Group Organizational. Management, 18 (2), 188-213. http://dx.doi.org/10.1177/1059601193182004

Cooper, D. R and Emory, C. W. (1995). Business research method, $5^{\text {th }}$ Edition. Richard D. Irwan, INC, US.

Cummings, J. (2007). The best and worst of working in IT. Network World. Framingham, 24(6), 37.

Curran, P. J., West, S. G., \& Finch, J. F. (1996). The robustness of test statistics to nonnormality and specification error in confirmatory factor analysis. Psychological Methods, 1, 16-29. http://dx.doi.org/10.1037/1082-989X.1.1.16

Davis, G. (2004). Job satisfaction survey among employees in small businesses. Journal of Small Business and Enterprise Development, 11(4), 495-503. http://dx.doi.org/10.1108/14626000410567143

De Witte, H. (1999). Job insecurity and psychological well-being: Review of the literature and exploration of some unresolved issues. European Journal of Work and Organizational Psychology, 8, 155-177. http://dx.doi.org/10.1080/135943299398302

DeLeon, L., \& Taher, W. (1996). Expectations and job satisfaction of local-government professionals. American Review of Public Administration, 26, 401-416. http://dx.doi.org/10.1177/027507409602600402

Delfgaauw, J. (2007). The effect of job satisfaction on job search: not just whether, but also where. Labour Economics, 14, 299-317. http://dx.doi.org/10.1016/j.labeco.2006.06.002

DeSantis, V. S., \& Durst, S. L. (1996). Comparing job satisfaction among public and private sector employees. American Review of Public Administration, 26, 327-343. http://dx.doi.org/10.1177/027507409602600305

Drafke, M., \& Kossen, S. (1998). The Human Side of Organisation. Addison Wesley, USA.

Duffy, R. D., \& Richard, G. V. (2006). Physician job satisfaction across six major specialties. Journal of Vocational Behavior, 68, 548-559. http://dx.doi.org/10.1016/j.jvb.2005.12.001

Ellickson, M., \& Logsdon, K. (2001). Determinants of job satisfaction of municipal government employees. State and Local Government Review, 33(3), 173-184. http://dx.doi.org/10.1177/0160323X0103300302

Ellickson, M.C. (2002). Determinants of job satisfaction of municipal employees. Public Personnel Management, 31(3), 343-358.

Emmert, M. A., \& Taher, W. A. (1992). Public sector professionals: The effects of public sector jobs on motivation, job satisfaction, and work involvement. American Review of Public Administration, 22, 37-49. http://dx.doi.org/10.1177/027507409202200103 
Eskildsen, J.K, Kristensen, K., and Westlund, A. (2003). Work motivation and job satisfaction in the Nordic countries. Employee Relations, 26(2), 122-136. http://dx.doi.org/10.1108/01425450410511043

Flecther, D. (2002). A network perspective of cultural organizing and "professional management" in the small, family business. Journal of Small Business and Enterprise Development, 9(4), 400-415.

Freund, A., and Carmeli, A. (2003). An empirical assessment: reconstructed model for five universal forms of work commitment. Journal of Managerial Psychology, 18(7), 708- 725. http://dx.doi.org/10.1108/02683940310502403

Friday, S.S., and Friday, E. (2003). Racioethnic perceptions of job characteristics and job satisfaction. Journal of Management Development, 22(5), 426-442. http://dx.doi.org/10.1108/02621710310474778

Friday, S.S., Moss, S.E and Friday, E. (2004). Socioethnic explanations for racioethnic differences in job satisfaction. Journal of Management Development, 23(.2), 152-168.

Garcia-Bernal, J., Gargallo-Castel, A., Marzo-Navarro, M., and Rivera-Torres, P. (2005). Job satisfaction: empirical evidence of gender differences. Women in Management Review, 20(4), 279-88. http://dx.doi.org/10.1108/09649420510599098

García-Serrano, C. (2004). Temporary employment, working conditions and expected exits from firms. Labour: Review of Labour Economics and Industrial Relations, 18, 293-316.

Gautam, M., Mandal, K., and Dalal, R.S. (2006). Job satisfaction of faculty members of veterinary sciences: an analysis. Livestock Research for Rural Development, 18 (7).

George, J.M. (1992). The Role of Personality in Organizational Life: Issues and Evidence. Journal of Management. 18(2), 185-213. http://dx.doi.org/10.1177/014920639201800201

George, J.M., \& Jones, G.R. (2008). Understanding and managing Organizational Behavior. (Fifth Edition). Upper SaddleRiver: New Jersey, Pearson Prentice Hall.

Ghazzawi I. (2010). Gender role in job satisfaction: the case of the u.s. information technology professionals. Journal of organizational culture, communications and conflict, 14(2), 1-35.

Ghazzawi, I. A. (2007). Motivation Through Setting Goals: Lessons Learned From a Technology Organization. The Journal of the Academy of Business Administration (ABA), Spring/Fall, 12, (1\&2).

Ghazzawi, I. A. (2008-a). Job Satisfaction Among Information Technology Professionals in the U.S.: An Empirical Study. Journal of American Academy of Business, Cambridge, 13(1), 1-15.

Ghazzawi, I. A. (2008-b). Job Satisfaction Antecedents and Consequences: A New Conceptual Framework and Research Agenda. The Business Review, Cambridge, 11(2), 1-10.

Ghazzawi, I., \& Smith Y. (2009). Crafting the Whole Employee: Job Satisfaction, Job Commitment, and Faith-A New Conceptual Framework and Research Agenda. The Business Review, Cambridge. 12(2), 300-309.

Greasley, K., Bryman, A., Dainty, A., Price, A., Soetano, R., and King, N. (2005). Employee perceptions of empowerment. Employee Relations, 27(4), 354-368. http://dx.doi.org/10.1108/01425450510605697

Greguras, G.J., Schleicher, D.J., and Watt, J.D. (2004). Reexamining the job satisfaction-performance relationship: the complexity of attitudes. Journal of Applied Psychology, 89(1), 165-77. http://dx.doi.org/10.1037/0021-9010.89.1.165

Güleryüz, G., Güney, S., Aydn, E. M., \& Aan, Ö. (2008). The mediating effect of job satisfaction between emotional intelligence and organisational commitment of nurses: A questionnaire survey. International Journal of Nursing Studies, 45, 1625-1635. http://dx.doi.org/10.1016/j.ijnurstu.2008.02.004

Hartline MD, \& Ferrell OC. (1996). The management of customer-contact service employees: anempirical investigation. Journal of Marketing, 60:52-70. http://dx.doi.org/10.2307/1251901

Herzberg, F. (1987). One more time: How do you motivate employees? Harvard Business Review, 65(5), 109-120.

Herzberg, F. (2003). One more time: How do you motivate employees? Harvard Business Review, 81(1), 86-97. Herzberg, F., Mausner, B., and Snyderman, B.B. (1959). The Motivation to Work. Wiley, New York, NY.

Hickson, C., and Oshagbemi, T. (1999). The effect of age on the satisfaction of academics with teaching and research. International Journal of Social Economics, 26(4), 537-544. http://dx.doi.org/10.1108/03068299910215960 
Hinkle, D. E., Wiersma, W., and Jurs, S. G. (1988). Applied statistics for the behavioural sciences. (2nd Ed.), Houghton-Mifflin, Boston.

Ho, J.T.S. (1997). Corporate wellness programmes in Singapore: effects on stress, satisfaction and absenteeism. Journal of Managerial Psychology, 12(3), 177-189. http://dx.doi.org/10.1108/02683949710174801

Holden, E.W., and Black, M.M. (1996). Psychologists in medical schools - professional issues for the future: how are rank and tenure associated with productivity and satisfaction? Professional Psychology: Research and Practice, 27(4), 407- 414. http://dx.doi.org/10.1037/0735-7028.27.4.407

Holt, G.D., Love, P.E.D., and Nesan, L.W. (2000). Employee empowerment in construction: an implementation model for process improvement. Team Performance Management: An International Journal, 6(3/4), 47-51. http://dx.doi.org/10.1108/13527590010343007

Ilies R, Wilson KS, \& Wagner DT. (2009). The spillover of daily job satisfaction onto employees' family lives: the facilitating role of work-family integration. Academic Management Journal, 52:87-102. http://dx.doi.org/10.5465/AMJ.2009.36461938

Irvine, D.M and Evans, M.G. (1995). Job satisfaction and turnover among nurses: integrating research findings across studies. Nursing Research, 44(4), 246-253.

Jernigan E, and Beggs J. (2010). Substitutes for leadership and job satisfaction: is there a relationship? Journal of Organizational Culture, Communications and Conflict, Volume 14, No. 2, 97-107.

Judge, T.A., \& Locke, R.J. (1993). Effect of dysfunctional thought processes on subjective well being and job satisfaction. Journal of Applied Psychology, 78(3), 475-490. http://dx.doi.org/10.1037/0021-9010.78.3.475

Jung, K., \& Moon, M. J. (2007). Do age, gender, and sector affect job satisfaction? Results from the Korean labor and income data panel data. Review of Public Personnel Administration, 27(2), 125-146. http://dx.doi.org/10.1177/0734371X06289229

Kamdron, T. (2005). Work motivation and job satisfaction of Estonian higher officials. International Journal of Public Administration, 28, 1211-1240. http://dx.doi.org/10.1080/01900690500241085

Karatepea, O. M., O. Uludag, I., Menevis, L., Hadzimehmedagic and L. Baddar. (2006). The effects of selected individual characteristics on frontline employee performance and job satisfaction. Tourism Management, 27, 547-560. http://dx.doi.org/10.1016/j.tourman.2005.02.009

Khojasteh, M. (1993). Motivating the private vs. public sector managers. Public Personnel Management, 22(3), 391-401.

Kim, S. (2002). Participative management and job satisfaction: Lessons for management leadership. Public Administration Review, 62, 231-241. http://dx.doi.org/10.1111/0033-3352.00173

Kim, S. (2004). Factors affection state government information technology employee turnover intentions. American Review of Public Administration, 35, 137-156. http://dx.doi.org/10.1177/0275074004273150

Kinicki, A.J., McKee-Ryan, R.M., Schriesheim, C.A., \& Carson, K.P. (2002). Assessing the Construct Validity of the Job Descritive Index: A review and Meta-Analysis. Journal of Applied Psychology, 87(1), 14-32. http://dx.doi.org/10.1037/0021-9010.87.1.14

Koustelios, A. (2001). Personal characteristics and job satisfaction of Greek teachers. International Journal of Educational Management, 15(7), 354-358. http://dx.doi.org/10.1108/EUM0000000005931

Koys, D.J. (2001). The efforts of employee satisfaction, organizational citizenship behavior, and turnover on organizational effectiveness, a unit-level, longitudinal study. Personnel Psychology, 54(1), 101-14. http://dx.doi.org/10.1111/j.1744-6570.2001.tb00087.x

Kreitner, R., \& Kinicki, A. (2007). Organizational Behavior. (7th Edition). Boston, MA: McGraw -Hill Irwin.

Krishnan, B. C., Netemeyer, R. G., \& Boles, J. S. (2002). Self-efficacy, competitiveness, and effort as antecedents of salesperson performance. Journal of Personal Selling \& Sales Management, 22(4), 285-295.

Kristensen, N., \& Westergård-Nielsen, N. (2004). Does low job satisfaction lead to job mobility?, Discussion Paper No. 1026, IZA.

Lévy-Garboua, L., Montmarquette, C., \& Simonnnet, V. (2007). Job satisfaction and quits. Labour Economics, 14, 251-268. http://dx.doi.org/10.1016/j.labeco.2005.08.003 
Lewis, G. (1991). Turnover and the quiet crisis in the federal civil service. Public Administration Review, 51, 145-155. http://dx.doi.org/10.2307/977108

Lewis, G. B., \& Frank, S. A. (2002). Who wants to work for government? Public Administration Review, 62(4), 395-404. http://dx.doi.org/10.1111/0033-3352.00193

Lin, H-F. (2007). Knowledge sharing and firm innovation capability: an empirical study. International Journal of Manpower, 28(3/4), 315-332. http://dx.doi.org/10.1108/01437720710755272

Locke, E., A., \& Latham, G., P. (1990). Work motivation and satisfaction. Light at the end of the tunnel. Psychological Science, 1(4):240-246. http://dx.doi.org/10.1111/j.1467-9280.1990.tb00207.x

Loosemore, M., Dainty, A., and Lingard, H. (2003). Human Resource Management in Construction Projects: Strategic and Operational Approaches. Spon Press, London

Love, P.E.D. (2002a). Influence of project type and procurement methods on rework costs in building construction projects. Journal of Construction and Engineering Management, 128(1), 18-29. http://dx.doi.org/10.1061/(ASCE)0733-9364(2002)128:1(18)

Love, P.E.D., and Edwards, D.J. (2005). Taking the pulse of UK construction project managers' health: Influence of job demands, job control and social support on psychological wellbeing. Engineering, Construction and Architectural Management, 12(1), 88-101. http://dx.doi.org/10.1108/09699980510576916

Lum, L., Kervin, J., Clark, K., Reid, F., \& Sirola, W. (1998). Explaining nursing turnover intent: job satisfaction, pay satisfaction or organizational commitment? Journal of Organizational Behaviour, 19, 305-320. http://dx.doi.org/10.1002/(SICI)1099-1379(199805)19:3<305::AID-JOB843>3.0.CO;2-N

Luthans, F. (2003). Positive organizational behavior: Developing and Managing PsychologicalStrengths. Academy of Management Executive, 16(1), 57-75. http://dx.doi.org/10.5465/AME.2002.6640181

Luthans, F., and Thomas, L.T. (1989). The relationship between age and job satisfaction: curvilinear results from an empirical study-a research note. Personnel Review, 18(1), 23-26. http://dx.doi.org/10.1108/00483488910133350

Malik. N. (2011). Study on job satisfaction factors of faculty members at university of Balochistan. International journal of academic research, 3(1), 2011, Part I

Mathieu, J., and Zajac, D. (1990). A review and meta-analysis of the antecedents, correlates and consequences of

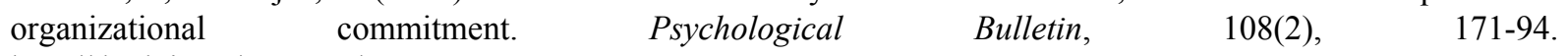
http://dx.doi.org/10.1037/0033-2909.108.2.171

McFarland, C., \& Buehler, R. (1995). Collective self-esteem as a moderator of the frogpond effect in reactions to performance feedback. Journal of Personality and Social Psychology, 68(6), 1055-1070. http://dx.doi.org/10.1037/0022-3514.68.6.1055

Mowday, R., Porter, L., \& Steers, R. (1982). Employee-Orientation Linkages: The Psychology of Commitment, Absenteeism and Turnover. Academic Press, New York.

Moyes, G.D., Williams, P.A., and Koch, B. (2006). The effects of age and gender upon the perceptions of accounting professionals concerning their job satisfaction and workrelated activities. Managerial Auditing Journal, 21(5), 536-561. http://dx.doi.org/10.1108/02686900610667292

Moynihan , D. P., and Pandey, S. K. (2007). Finding Workable Levers over Work Motivation: Comparing Job Satisfaction, Job Involvement, and Organizational Commitment. Administration \& Society, 39(7), 803-832. http://dx.doi.org/10.1177/0095399707305546

Naff, K. C., \& Crum, J. (1999). Working for America: Does public service motivation make a difference? Review of Public Personnel Administration, 19(4), 5-16. http://dx.doi.org/10.1177/0734371X9901900402

O'Neill, B. S., \& Mone, M. A. (1998). Investigating equity sensitivity as a moderator of relations between self-efficacy and workplace attitudes. Journal of Applied Psychology, 83(5), 805-816. http://dx.doi.org/10.1037/0021-9010.83.5.805

Ogunlewe, Senator Seye; Honourable Minister of Works, Federal Republic of Nigeria, (Abuja: Speech at public hearing of the Senate on Due Process and Procurement Bill, November, 2005)

Okpara, J.O. (2004). Personal characteristicsas predictors of job satisfaction. Information Technology and People, 17(3), 327- 338. http://dx.doi.org/10.1108/09593840410554247 
Oshagbemi, T. (1999). Overall job satisfaction: how good are single versus multiple-item. measures?, Journal of Managerial Psychology, 14(5), 388-403. http://dx.doi.org/10.1108/02683949910277148

Oshagbemi, T. (2000a). Gender differences in the job satisfaction of university teachers. Women in Management Review, 15(7), 331-343. http://dx.doi.org/10.1108/09649420010378133

Oshagbemi, T. (2000b). Is length of service related to the level of job satisfaction?, International Journal of Social Economics, 27(3), 213-226. http://dx.doi.org/10.1108/03068290010286546

Oshagbemi, T. (2003). Personal correlates of job satisfaction: empirical evidence from UK universities. International Journal of Social Economics, 30(12), 1210-1232. http://dx.doi.org/10.1108/03068290310500634

Oshagbemi, T. (2004). Age influences on the leadership styles and behaviour of managers. Employee Relations, 26(1), 14-29. http://dx.doi.org/10.1108/01425450410506878

Oshagbemi, T., and Hickson, C. (2003). Some aspects of overall job satisfaction: a binomial logit model. Journal of Managerial Psychology, 18(4), 357-367. http://dx.doi.org/10.1108/02683940310473109

Oyewobi, L.O., Ibironke, O.T, Ganiyu, B. O and Ola-awo, A. W. (2011). Evaluating rework cost - A study of selected building projects in Niger State, Nigeria. Journal of Geography and Regional Planning, (online academic journal) 4 (3), 147-151,

Rad, A.M.M., and Yarmohammadian, M.H. (2006). A study of relationship between managers leadership style and employees' job satisfaction. Leadership in Health Services, 19(2), xi-xxviii.

Reisel, W. D., Chia, S., Maloles, C. M., and J. W. Slocum, Jr. (2007). The Effects of Job Insecurity on Satisfaction and Perceived Organizational Performance. Journal of Leadership \& Organizational Studies, 14(2), 106-116. http://dx.doi.org/10.1177/1071791907308055

Rhodes, S. (1983). Age-related differences in work attitudes and behaviour: a review and conceptual analysis. Psychological Bulletin, 2: 326-367.

Robbins, S.P., \& Judge, T. A. (2009). Organizational Behavior. (Thirteenth Edition). Upper Saddle River: New Jersey,Pearson Prentice Hall.

Rosnowski, M., \& Hulin, C. (1992). The scientific merit of valid measures of general constructs with special reference to job satisfaction and job withdrawal. In C. J. Their jobs and how it affects their performance. Lexington Books: New York.

Rue, L.W., \& Byars, L.L. (2005). Management: Skills and Application (Eleventh Edition). New York: New York. The McGraw Hill Companies

Ruthankoon, R., and Ogunlana, S.O. (2003). Testing Herzberg's two-factor theory in the Thai construction industry. Engineering, Construction and Architectural Management, 10(5), 333-341. http://dx.doi.org/10.1108/09699980310502946

Schneider B, \& Bowen D. E. (1985). Employee and customer perceptions of service in banks: replication and extension. Journal of Applied Psychology, 70:423-33. http://dx.doi.org/10.1037/0021-9010.70.3.423

Schwepker Jr, C. H. (2001). Ethical climate's relationship to job satisfaction, organizational commitment, and turnover intention in the salesforce. Journal of Business Research, 54, 39- 52. http://dx.doi.org/10.1016/S0148-2963(00)00125-9

Sekaran, U. (2003). Research methods for business: a skill-building approach, (2 ${ }^{\text {ed }}$ Edition). John Wiley \& Sons, US.

Sekaran, U. (2005). Research Methods for Business: A Skill-building Approach (4 ${ }^{\text {th }}$ ed.). New York: John Wiley $\&$ Sons.

Shields, M.A., \& Price, S.W. (2002). Racial harassment, job satisfaction and intentions to quit: evidence from the British nursing profession. Economica, 69, 295- 326. http://dx.doi.org/10.1111/1468-0335.00284

Sloane, P., and Williams, H. (2000). Job satisfaction, comparison earnings, and gender. Labour, 14(3), 473-502. http://dx.doi.org/10.1111/1467-9914.00142

Sousa-Poza, A., \& Henneberger, F. (2004). Analyzing job mobility with job turnover intentions: an international comparative study. Journal of Economic Issues, 38, 113-137.

Steijn, B. (2004). Human resource management and job satisfaction in the Dutch public sector. Review of Public Personnel Administration, 24(4), 291-303. http://dx.doi.org/10.1177/0734371X04269187 
Sverke, M., Hellgren, J., \& Na“swall, K. (2002). No security: A meta-analysis and review of job insecurity and its consequences. Journal of Occupational Health Psychology, 7, 242-264. http://dx.doi.org/10.1037/1076-8998.7.3.242

Tait M, Padgett M. Y, \& Baldwin T. T. (1989). Job and life satisfaction: a reevaluation of the strength of the relationship and gender effects as a function of the date of the study. Journal of Applied Psychology, 74:502-7. http://dx.doi.org/10.1037/0021-9010.74.3.502

Ting, Y. (1997). Determinants of job satisfaction of federal government employees. Public Personnel Management, 26, 313-334.

Tovey, E., \& Adams, A. (1999). The changing nature of nurses' job satisfaction: an exploration of sources of satisfaction in the 1990s. Journal of Advanced Nursing, 30 (1), 150-158. http://dx.doi.org/10.1046/j.1365-2648.1999.01059.x

Tziner, A. (2006). A revised model of work adjustment, work attitudes, and work behavior. Review of Business Research, 6, 34-40.

Tziner, A., Manor, R.W., Vardl, N., and Brodman, A. (2008). The personality dispositional approach to job satisfaction and organizational commitment. Psychological Reports, 103, 435-42.

Udo, J.G., Guimaraes, T., \& Igbaria, M. (1997). An investigation of the antecedents of turnover intention for manufacturing plant managers. Int. J. Oper. Prod. Manage, 17 (9), 912-930. http://dx.doi.org/10.1108/01443579710171280

Ward, M.E., \& Sloane, P.J. (2000). Non-pecuniary advantages versus pecuniary disadvantages; job satisfaction among male and female academics in Scottish Universities. Scottish Journal of Political Economy, 47.3, 273-303. http://dx.doi.org/10.1111/1467-9485.00163

Wasko, M.M., \& Faraj, S. (2005). Why should I share? Examining social capital and knowledge contribution in electronic networks of practices. MIS Quarterly, 29(1), 35-57.

Westover, J. H., Westover, A. R., and Westover, L. A. (2010). Enhancing long-term worker productivity and performance: The connection of key work domains to job satisfaction and organizational commitment. International Journal of Productivity and Performance Management, 59 (4), 372-387. http://dx.doi.org/10.1108/17410401011038919

Wright, B. E., \& Davis, B. S. (2003). Job satisfaction in the public sector: The role of the work environment. American Review of Public Administration, 33, 70-90. http://dx.doi.org/10.1177/0275074002250254

Wright, B.E., \& Kim, S. (2004). Participation's influence on job satisfaction: The importance of job satisfaction: The importance of job characteristics. Review of Public Personnel Administration, 24(1), 18-40. http://dx.doi.org/10.1177/0734371X03259860

Wright, T.A., Cropanzano, R., and Bonett, D.G. (2007). The moderating role of employee positive well being on the relationship between job satisfaction and job performance. Journal of Occupational Health Psychology, 12, (2), 93-104. http://dx.doi.org/10.1037/1076-8998.12.2.93

Yagil, D. (2002). The relationship of customer satisfaction and service workers' perceived control, Examination of the three models. International Journal of Service Industry Management, 13(4), 382-398. http://dx.doi.org/10.1108/09564230210445032

Yousef, D.A. (1998). Satisfaction with job security as a predictor of organizational commitment and job performance in a multicultural environment. International Journal of Manpower, 19, (3), 184-194. http://dx.doi.org/10.1108/01437729810216694

Zeinabadi, H. (2010). Job satisfaction and organizational commitment as antecedents of Organizational Citizenship Behavior (OCB) of teachers. Procedia Social and Behavioral Sciences, 5, 998-1003. http://dx.doi.org/10.1016/j.sbspro.2010.07.225

Zellars, K. L., Hochwarter, W. A., Perrewe, P. L., Miles, A. K., \& Kiewitz, C. (2001). Beyond self-efficacy: Interactive effects of role conflict and perceived collective efficacy. Journal of Managerial Issues, 8(4), 483-499. 
Table 1. Job satisfaction variables

\begin{tabular}{|l|l|l|l|l|l|}
\hline \multicolumn{1}{|c|}{ Variables } & mean & $\begin{array}{l}\text { standard } \\
\text { Error }\end{array}$ & $\begin{array}{l}\text { Standard } \\
\text { deviation }\end{array}$ & skewness & kurtosis \\
\hline $\begin{array}{l}\text { Job Satisfaction } \\
\text { All in all, I am satisfied with my job. }\end{array}$ & 3.75 & 0.122 & 0.868 & -1.806 & 1.109 \\
$\begin{array}{l}\text { ACH How satisfied are you with your opportunities for } \\
\text { achievement? }\end{array}$ & 3.255 & 0.112 & 0.796 & -0.251 & -0.908 \\
$\begin{array}{l}\text { REC How satisfied are you with your recognition } \\
\text { opportunities? } \\
\text { RES How satisfied are you with your level of responsibility on }\end{array}$ & 3.803 & 0.128 & 0.917 & -1.374 & 2.372 \\
$\begin{array}{l}\text { your job? } \\
\text { MEN How satisfied are you with the meaningfulness of your } \\
\text { job? }\end{array}$ & 3.294 & 0.144 & 1.026 & -0.399 & -1.116 \\
$\begin{array}{l}\text { ADV How satisfied are you with your advancement } \\
\text { opportunities? }\end{array}$ & 3.275 & 0.14 & 1.002 & 0.034 & -1.651 \\
\hline
\end{tabular}

Table 2. Organisational commitment

\begin{tabular}{|llllll|}
\hline \multicolumn{1}{|c}{ Variables } & mean & $\begin{array}{l}\text { standard } \\
\text { Error }\end{array}$ & $\begin{array}{l}\text { Standard } \\
\text { deviation }\end{array}$ & skewness & kurtosis \\
\hline $\begin{array}{l}\text { Organizational Commitment } \\
\text { This organization deserves my loyalty. }\end{array}$ & 3.549 & 0.146 & 1.045 & -2.049 & 2.431 \\
I would not leave my organization right now because & & & & & \\
I have a sense of obligation to the peoplein it. & 3.294 & 0.126 & 0.901 & -1.142 & 0.464 \\
I owe a great deal to my organization. & 3.392 & 0.119 & 0.85 & -0.461 & -0.826 \\
The feeling of accomplishment I get from the job & 3.784 & 0.135 & 0.966 & -1.209 & 1.55 \\
The praise I get for doing a good job & 3.412 & 0.129 & 0.92 & -0.611 & -1.047 \\
The way my co-workers get along with each other & 3.255 & 0.142 & 1.017 & -0.052 & -0.742 \\
\hline
\end{tabular}

Table 3. Correlation between Job satisfaction and Job Commitment

\begin{tabular}{|c|l|c|c|c|c|c|c|c|c|c|c|}
\hline & ACH & REC & RES & MEN & ADV & LOY & OBL & OWE & ACO & PRS & REL \\
\hline ACH & 1.000 & & & & & & & & & & \\
REC & $0.398^{* *}$ & 1.000 & & & & & & & & & \\
RES & -0.191 & -0.235 & 1.000 & & & & & & & & \\
MEN & 0.136 & 0.147 & $0.407^{* *}$ & 1.000 & & & & & & & \\
ADV & 0.253 & $0.336^{*}$ & 0.032 & 0.244 & 1.000 & & & & & & \\
LOY & $0.357^{*}$ & $0.407^{* *}$ & -0.247 & 0.044 & -0.092 & 1.000 & & & & & \\
OBL & $0.451^{* *}$ & $0.604^{* *}$ & -0.052 & 0.263 & $0.347^{*}$ & $0.505^{* *}$ & 1.000 & & & & \\
OWE & $0.499^{* *}$ & $0.28^{*}$ & -0.043 & -0.050 & 0.022 & $0.405^{* *}$ & $0.342^{*}$ & 1.000 & & & \\
ACO & $0.307^{*}$ & $0.855^{* *}$ & -0.339 & 0.021 & 0.222 & $0.377^{* *}$ & $0.534^{* *}$ & $0.324^{*}$ & 1.000 & & \\
PRS & -0.146 & -0.021 & $0.59^{* *}$ & $0.417^{* *}$ & 0.039 & 0.155 & 0.116 & 0.045 & -0.146 & 1.000 & \\
REL & 0.231 & $0.502^{* *}$ & $0.331^{*}$ & 0.570 & $0.372^{* *}$ & 0.264 & $0.559^{* *}$ & 0.201 & $0.396^{* *}$ & $0.404^{* *}$ & 1.000 \\
\hline
\end{tabular}

${ }^{* *}$. Correlation is significant at the 0.01 level (2-tailed).

*. Correlation is significant at the 0.05 level (2-tailed). 